\title{
THE EFFECTS OF $\alpha_{10}$-ADRENERGIC RECEPTORS ON SHEDDING OF BIOLOGICALLY ACTIVE EGF IN FRESHLY ISOLATED LACRIMAL GLAND EPITHELIAL CELLS
}

\author{
LiLi Chen ${ }^{1}$, Robin R. Hodges ${ }^{1},{ }^{*}$, Chika Funaki $^{1}$, Driss Zoukhri ${ }^{2}$, Robert J. Gaivin ${ }^{3}$, Dianne \\ M. Perez ${ }^{3}$, and Darlene A. Dartt ${ }^{1}$ \\ 1 Schepens Eye Research Institute and Department of Ophthalmology, Harvard Medical School, \\ Boston, MA
}

\section{Tufts University School of Dental Medicine, Boston, MA}

3 Lerner Research Institute, The Cleveland Clinic, Cleveland, $\mathrm{OH}$

\begin{abstract}
Transactivation of EGF receptors by G-protein coupled receptors is a well-known phenomenon. This process involves the ectodomain shedding of growth factors in the EGF family by matrix metalloproteinases. However, many of these studies employ transformed and/or cultured cells that overexpress labeled growth factors. In addition, few studies have shown that EGF itself is the growth factor that is shed and is responsible for transactivation of the EGF receptor. In this study, we show that freshly isolated, non-transformed lacrimal gland acini express two of the three known $\alpha_{1}$ adrenergic receptors (ARs), namely $\alpha_{1 B^{-}}$and $\alpha_{1 D^{-}}$ARs. $\alpha_{1 D^{-}}$ARs mediate phenylephrine (an $\alpha_{1^{-}}$ adrenergic agonist)-induced protein secretion and activation of p42/p44 MAPK because the $\alpha_{1 \mathrm{D}}$-AR inhibitor BMY-7378, but not the $\alpha_{1 \mathrm{~A}}$-AR inhibitor 5-methylurapidil, inhibits these processes.

Activation of p42/p44 MAPK occurs through transactivation of the EGF receptor, which is inhibited by the matrix metalloproteinase ADAM17 inhibitor TAPI-1. In addition, phenylephrine caused the shedding of EGF from freshly isolated acini into the buffer. Incubation of freshly isolated cells with conditioned buffer from cells treated with phenylephrine resulted in activation of the EGF receptor and p42/p44 MAPK. The EGF receptor inhibitor AG1478 and an EGF-neutralizing antibody blocked this activation of p42/p44 MAPK. We conclude that in freshly isolated lacrimal gland acini, $\alpha_{1^{-}}$ adrenergic agonists activate the $\alpha_{1 \mathrm{D}}$-AR to stimulate protein secretion and the ectodomain shedding of EGF to transactivate the EGF receptor, potentially via ADAM17, which activates p42/p44 MAPK to negatively modulate protein secretion.
\end{abstract}

\section{Keywords}

EGF ectodomain shedding; protein secretion; adrenergic receptors; signal transduction

\section{INTRODUCTION}

Three types of $\alpha_{1}$-adrenergic receptors (ARs), $\alpha_{1 \mathrm{~A}^{-}}, \alpha_{1 \mathrm{~B}^{-}}$, and $\alpha_{1 \mathrm{D}^{-}}$subtypes, have been identified by biochemical and molecular biology techniques (23). These receptors are members of the G-protein-coupled receptor (GPCR) superfamily. The signaling pathways used by these subtypes are cell-specific but the agonists generally activate either phospholipases $\mathrm{C}$ or $\mathrm{A}_{2}$

\footnotetext{
* Address correspondence to: Robin R. Hodges, Schepens Eye Research Institute, 20 Staniford Street, Boston, MA 02114. Tel: 617-912-7424; FAX: 617-912-0104; email: hodges@ vision.eri.harvard.edu.

Supported by: NIH EY06177
} 
(23). There are, however, differences in coupling efficiencies of the receptors to the signaling pathways (23). $\alpha_{1}$-ARs are expressed in many tissue types, most notably in vascular tissues where they typically regulate smooth muscle contraction (7). In particular, the only function directly attributed to $\alpha_{1 \mathrm{D}}$-adrenergic receptors is as a mediator of contraction of large arteries such as the aorta, femoral, iliac, and superior mesenteric arteries (23).

Similar to other members of its family, EGF is synthesized as a glycosylated membraneanchored precursor protein (precursor EGF) that is proteolytically cleaved to release the soluble form (proEGF). ProEGF is further cleaved to release the mature $6 \mathrm{kDa}$ form of EGF. All forms of the proteins are thought to be biologically active (16). The process by which EGF family members are released is known as ectodomain shedding, and is mediated mainly by metalloproteinases (MMP). In particular, ADAM 10 (a disintegrin and metalloproteinase) has been shown to be the MMP involved in shedding of EGF and betacellulin (26) whereas ADAM17 (also known as TACE) has been shown to be responsible for the shedding of transforming growth factor $\alpha$ (TGF $\alpha$ ), amphiregulin, and heparin-binding EGF (HB-EGF) $(3,11,22,26)$. GPCRs have been shown to activate the MMPs that then cleave the precursor form of the growth factors. The precursor growth factor can then bind to and activate the EGF receptor (24). This mode of EGF receptor activation is known as the "triple membrane passing signal" model (24).

Numerous studies have documented the effects of activation of GPCRs and the subsequent transactivation of the EGF receptor through the triple membrane passing signal model (17, $21,27,37)$. Ectodomain shedding of two members of the EGF family, TGF $\alpha$ and HB-EGF, occurs in multiple tissues with stimulation by a variety of GPCR agonists (25). In contrast, there are only two reports to date documenting the ectodomain shedding of EGF $(13,26)$. In addition, few studies have quantified the amount of the released growth factors as a result of activation of GPCRs. Those that have quantified the amount of growth factors have relied on transfected cells expressing labeled growth factors $(6,13,26,32)$ or cells grown in culture (17). There have been no studies quantifying the shedding of growth factors from nontransformed, non-cultured, freshly isolated cells.

The exocrine lacrimal gland is the major contributor to the aqueous component of the tear film. As a result, protein, electrolyte and water secretion from this gland is tightly regulated by parasympathetic and sympathetic nerves that innervate the gland (9). We have previously shown that $\alpha_{1}$-adrenergic agonists released from sympathetic nerves are potent stimuli of protein secretion from the lacrimal gland (9). $\alpha_{1}$-Adrenergic agonists increase cGMP which stimulates lacrimal gland protein secretion (10). It is also known that phenylephrine (an $\alpha_{1-}$ adrenergic agonist in the lacrimal gland) activates protein kinase $\mathrm{C}$ (PKC) $-\varepsilon$, which stimulates protein secretion, and PKC $\alpha$ and $-\delta$ which inhibit secretion. In addition, we have shown that $\alpha_{1}$-adrenergic agonists transactivate the EGF receptor, recruiting Shc and Grb2 to activate p42/ p44 MAPK. When p42/p44 MAPK activation is inhibited by U0126 (an inhibitor of MEK), $\alpha_{1}$-adrenergic agonist-stimulated protein secretion is increased. Thus, activation of $\mathrm{p} 42 / \mathrm{p} 44$ MAPK reduces protein secretion and acts to negatively modulate protein secretion from the lacrimal gland (21). Therefore, $\alpha_{1}$-adrenergic agonists activate two antagonistic pathways, resulting in a net increase in protein secretion.

As lacrimal gland acini are polarized with tight junctions present between cells, the location of EGF is of particular interest. Any EGF molecule located in the apical membrane of acinar cells would be shed into the ducts and then into the tears upon stimulation. Thus this EGF would be interacting with any EGF receptors on the cells of the ocular surface. In contrast, EGF located in the basal and/or lateral membrane of acinar cells would be shed upon stimulation into the extracellular space and would bind to the EGF receptor on acinar cells thus 
having effects on the acinar cells themselves. We have shown that addition of exogenous EGF stimulates protein secretion from the lacrimal gland (34).

In this study, we identify the $\alpha_{1}$-adrenergic receptor subtypes present in the lacrimal gland and their effects on the shedding of EGF from freshly isolated epithelial cells of the lacrimal gland.

\section{MATERIALS AND METHODS}

\section{Materials}

${ }^{125}$ I-HEAT was purchased from Perkin-Elmer (Boston, MA). Rat EGF was obtained from Biomedical Technologies, Inc. (Stoughton, MA). Collagenase type III (CLSIII) was from Worthington Biochemical (Lakewood, NJ). RNA extraction reagent (TRIzol) was from GibcoBRL (Grand Island, NY); Reverse Transcription System and PCR Core System II were purchased from Promega (Madison, WI). Amplex Red was purchased from Molecular Probes (Eugene, OR). Enhanced chemiluminescent substrate for detection of horseradish peroxidase (HRP) was from Pierce (Rockford, IL). GM6001 (N-[(2R)-2-

(Hydroxamidocarbonylmethyl)-4-methylpentanoyl]-L-tryptophan Methylamide), its negative control N-t-butoxycarbonyl-L-leucyl-L-tryptophan methylamide and TAPI-1 (N-(R)-[2(Hydroxyaminocarbonyl)methyl]-4-methylpentanoyl-L-naphthylalanyl-L-alanine, 2aminoethylamide), were purchased from EMD Biosciences, Inc. (San Diego, CA). EGF was purchased from Peprotech (Rocky Hill, NJ). All other reagents were from Sigma Chemical Company (Saint Louis, MO).

\section{Antibodies}

Anti-rat EGF polyclonal antibody immunohistochemical grade was purchased from Biomedical Technologies, Inc. (Stoughton, MA). A second anti-rat EGF polyclonal antibody raised against a peptide corresponding to the carboxy terminus of the mature form of EGF of rat origin was obtained from Santa Cruz Biotechnology (Santa Cruz, CA) and used in Western blot analyses. Anti-human EGF receptor polyclonal antibody used for immunohistochemistry was from Cell Signaling Technology, Inc (Beverly, MA). Anti-human EGF receptor polyclonal antibody used for Western blot analyses was from Santa Cruz Biotechnology (Santa Cruz, CA). Anti-EGF receptor used for immunoprecipitation was obtained from Upstate (Charlottesville, VA). Anti-EGF receptor [pY $\left.{ }^{1086}\right]$ phosphospecific polyclonal antibody was from BioSource International, Inc (Camarillo, CA). Anti-actin monoclonal antibody was from Chemicon International (Temecula, CA). Monoclonal antibodies generated against p42 MAPK and phosphorylated p42/p44 MAPK, which specifically reacts with Tyr-204 of phosphorylated ERK1 and ERK2, were from Santa Cruz Biotechnology. The secondary antibody for immunohistochemistry, fluorescein isothiocyanate (FITC) conjugated donkey anti-rabbit IgG, was purchased from Jackson ImmunoResearch Laboratories, Inc. (West Grove, PA). HRP conjugated secondary antibodies for Western blot analyses were from Santa Cruz Biotechnology.

\section{Animals}

Male Sprague-Dawley rats weighing between $125-150 \mathrm{~g}$ were obtained from Taconic Farms (Germantown, NY). They were maintained in constant temperature rooms with fixed light/ dark intervals of 12 hours and were fed ad libitum. The rats were anesthetized for 1 minute in $\mathrm{CO}_{2}$, decapitated, and both exorbital lacrimal glands were removed. All experiments were approved by the Schepens Eye Research Institute Animal Care and Use Committee. 


\section{Immunohistochemistry}

Lacrimal glands were fixed by immersion in $4 \%$ formaldehyde diluted in phosphate-buffered saline (PBS, $145 \mathrm{mM} \mathrm{NaCl}, 7.3 \mathrm{mM} \mathrm{Na}_{2} \mathrm{HPO}_{4}$, and $2.7 \mathrm{mM} \mathrm{NaH}_{2} \mathrm{PO}_{4}, \mathrm{pH} 7.2$ ) at $4{ }^{\circ} \mathrm{C}$ overnight. After cryopreservation in 10-30\% sucrose dissolved in PBS, the tissue was frozen in O.T.C embedding medium (Tissue Tek, Sakura, Torrance, CA). Cryostat sections (6 $\mu \mathrm{m})$ were placed on slides and air-dried. The sections were rinsed in PBS, permeabilized in PBS containing $1 \%$ Triton $\mathrm{X}-100$, and non-specific binding of $\mathrm{IgG}$ was blocked by preincubation with PBS containing $10 \%$ bovine serum albumin (BSA). The sections were then incubated with the primary antibody for 2 hours at room temperature. The secondary antibody was applied for 1 hour at room temperature. Negative controls consisting of omission of the primary antibody were performed with each experiment. The sections were viewed with a Nikon Eclipse E800 microscope and pictures were taken with a SPOT Diagnostic Instruments Inc. camera.

\section{Preparation of Lacrimal Gland Acini}

Lacrimal glands were trimmed, fragmented, and incubated with collagenase in Krebs-Ringer bicarbonate (KRB) buffer (119 mM NaCl, $4.8 \mathrm{mM} \mathrm{KCl}, 1 \mathrm{mM} \mathrm{CaCl}_{2}, 1.2 \mathrm{mM} \mathrm{MgSO}_{4}, 1.2$ $\mathrm{mM} \mathrm{KH}_{2} \mathrm{PO}_{4}$, and $25 \mathrm{mM} \mathrm{NaHCO}_{3}, 10 \mathrm{mM} \mathrm{N}$-2-hydroxyethylpiperazine- $N$ '-2-ethanesulfonic acid (HEPES), $5.5 \mathrm{mM}$ glucose) and $0.5 \%$ bovine serum albumin (BSA). Lobules were subjected to gentle pipetting through tips of decreasing diameter, filtered through nylon mesh ( $150 \mu \mathrm{m}$ pore size), and centrifuged briefly. The pellet was washed twice by centrifugation (50 $\times \mathrm{g}, 2$ minutes) through a $4 \%$ BSA solution made in KRB buffer. The dispersed acini were allowed to recover for 60 minutes in fresh KRB with $0.5 \%$ BSA.

\section{Membrane Binding Studies}

Freshly isolated acini were homogenized in homogenization buffer $(30 \mathrm{mM}$ Tris- $\mathrm{HCl} \mathrm{pH} 7.5$, $10 \mathrm{mM}$ EDTA, $5 \mathrm{mM}$ EGTA, $1 \mathrm{mM}$ dithiothreitol, and $250 \mathrm{mM}$ sucrose supplemented with $10 \mu \mathrm{l} / \mathrm{ml}$ protease inhibitor cocktail (Sigma, St. Louis MO) and centrifuged at $100,000 \times \mathrm{g}$ for 60 minutes. The membrane fraction was resuspended in cold buffer consisting of $20 \mathrm{mM}$ HEPES pH 7.4, $1.4 \mathrm{mM}$ EDTA, $12.5 \mathrm{mM} \mathrm{MgCl} 2$ containing protease inhibitors, rehomogenized with a motorized Potter-Elvehjem PTFE Tissue Grinder (Fisher Scientific, Pittsburgh PA), and diluted to a protein concentration of $60 \mu \mathrm{g}$ per assay tube with cold HEM buffer (20 mM HEPES pH 7.4, $12.5 \mathrm{mM} \mathrm{MgCl} 2,1.5 \mathrm{mM}$ EGTA).

Saturation studies were performed by incubating the diluted membranes with increasing concentrations $(35-600 \mathrm{pM})$ of ${ }^{125} \mathrm{I}$-HEAT in the presence and absence of $0.1 \mathrm{mM}$ phentolamine for $1 \mathrm{~h}$ at $22^{\circ} \mathrm{C}$. Competition studies were performed using either the $\alpha_{1 \mathrm{~A}}$-AR inhibitor 5-methylurapidil (5-MU) or $\alpha_{1 \mathrm{D}}$-AR inhibitor BMY-7378 from $10 \mathrm{pM}$ to $1 \mathrm{mM}$ in the presence of $90 \mathrm{pM}^{125} \mathrm{I}$-HEAT for $1 \mathrm{~h}$ at $22^{\circ} \mathrm{C}$. Samples were then filtered on a BRANDEL Cell Harvester through Whatman GF/C filter paper which had been pretreated with $0.3 \%$ (v/ v) polyethylenimine $/ \mathrm{dH}_{2} \mathrm{O}$ and $0.1 \%$ (w/v) BSA and washed with cold $\mathrm{HEM}$ buffer. Filters were counted on a gamma counter for 1 minute and data was analyzed using GraphPad Prism 3.0 (GraphPad Software, Inc, San Diego, CA) by nonlinear regression. Determination of one versus two site curves was determined using a F-test.

\section{Measurement of Protein Secretion}

Lacrimal gland acini were preincubated in KRB buffer containing 0.5\% BSA in the presence of 5-MU, BMY-7378, GM6001, its negative control compound, or TAPI-1 at varying concentrations for 20 minutes at $37{ }^{\circ} \mathrm{C}$ followed by the addition of the $\alpha_{1}$-adrenergic agonist phenylephrine (10-4 M) for 20 minutes. Peroxidase (our marker for protein secretion) was measured using Amplex Red (Molecular Probes, Eugene OR). The amount of fluorescence was quantified by a fluorescence microplate reader (model FL600; Bio-Tek, Winooski, VT) 
with $530 \mathrm{~nm}$ excitation wavelength and $590 \mathrm{~nm}$ emission wavelength. The amount of peroxidase in the supernatant (secreted) was expressed as a percentage of the total peroxidase (amount of peroxidase present in the supernatant plus the amount remaining in the cells) (21).

\section{Western Blot Analyses}

Lacrimal gland acini or tissue pieces were incubated at $37^{\circ} \mathrm{C}$ in the absence or presence of phenylephrine at $10^{-4} \mathrm{M}$ in KRB buffer with $0.5 \%$ BSA for $10-120$ minutes. In some experiments the ADAM 17 inhibitor TAPI- $1\left(10^{-4}-10^{-6} \mathrm{M}\right)$ was added 20 minutes prior to addition of phenylephrine. The acini or tissue pieces were then homogenized in RIPA buffer (10 mM Tris-HCl, pH7.4, $150 \mathrm{mM} \mathrm{NaCl}, 1 \%$ sodium deoxycholate, $1 \%$ Triton X-100, $0.1 \%$ SDS, $1 \mathrm{mM}$ EDTA) in the presence of a protease inhibitor cocktail (Sigma, St. Louis, MO) and centrifuged at $20,000 \times \mathrm{g}$ for 30 minutes. Proteins in the supernatant were separated by SDS-PAGE on a $10 \%$ gel or 4-20\% linear gradient gel. Separated proteins were transferred onto nitrocellulose membranes, blocked in 5\% non-fat dried milk in buffer containing $10 \mathrm{mM}$ Tris- $\mathrm{HCl}, \mathrm{pH} 8.0,150 \mathrm{mM} \mathrm{NaCl}$, and $0.05 \%$ Tween-20 (TBST) 1 hour at room temperature, and incubated with the primary antibody made up in 5\% dried milk-TBST overnight at $4{ }^{\circ} \mathrm{C}$. After washing, the membranes were incubated with the appropriate HRP conjugated secondary antibody for 1 hour. Immunoreactive bands were detected by the enhanced chemiluminescence method. The films were digitally scanned and analyzed with NIH Image software (version 1.63, Bethesda, MD). The amount of phosphorylated MAPK in each sample was standardized to the amount of total MAPK.

\section{RNA Extraction and Reverse Transcription Polymerase Chain Reaction}

Total RNA was isolated lacrimal gland acini or brain using the extraction reagent TriZol according to the manufacturer's protocol. One microgram of purified total RNA was used for complementary DNA (cDNA) synthesis using Reverse Transcription System as described in the manufacturer's instructions. The absence of genomic DNA in RNA preparations was verified by omitting the reverse transcriptase in the reaction. The cDNA was amplified by PCR in a thermal cycler (PCR Sprint; Thermo Hybaid, Ashton, UK). The sense and antisense oligonucleotide primers were derived from previously published sequences and are as follows: $\alpha_{1 \mathrm{~A}}$-AR, 5' GTA GCC AAG AGA GAA AGC CG 3', 5'CAA CCC ACC ACG ATG CCC AG 3', 212 base pair product; $\alpha_{1 B^{-}}$AR, 5' GCT CCT TCT ACA TCC CGC TCG 3', 5' AGG GGA GCC AAC ATA AGA TGA 3', 300 base pair product; $\alpha_{1 D^{-}}$AR 5' CGT GTG CTC CTT CTA CCT ACC 3', 5' GCA CAG GAC GAA GAG ACC CAC 3', 304 base pair product. The glyceraldehyde-3-phosphate dehydrogenase (G3PDH) gene was used as the internal control. Primers for G3PDH were purchased from Clonetech Laboratories (Palo Alto, CA). Each PCR reaction consisted of $0.5 \mu \mathrm{M}$ each of sense and antisense primer, $200 \mathrm{oM}$ each of dNTP, 1.5 $\mathrm{mM} \mathrm{MgCl} 2,1.25$ units of Taq polymerase, and 1 ol of cDNA. For $\alpha_{1}$-adrenergic receptors, PCR was performed after a 5 -minute hot start at $94^{\circ} \mathrm{C}$ followed by 35 cycles of denaturation for 1 minute, annealing for 1.5 minutes at $55^{\circ} \mathrm{C}$, and extension for 1.5 minute at $72^{\circ} \mathrm{C}$. The final elongation time step was performed at $72^{\circ} \mathrm{C}$ for 7 minutes. 30 (G3PDH) cycles of denaturation for 1 minute at $94^{\circ} \mathrm{C}$, annealing for 1 minute at $55^{\circ} \mathrm{C}$, and extension for 1.5 minute at $72^{\circ} \mathrm{C}$. The final elongation time step was performed at $72^{\circ} \mathrm{C}$ for 7 minutes. Sample with no cDNA was also amplified as negative control in every reaction. After amplification, $10 \mu \mathrm{l}$ of products were separated by electrophoresis on a $1.2 \%$ agarose gel and visualized by ethidium bromide staining.

\section{Measurement of EGF release by enzyme-linked immunosorbent assay}

Lacrimal gland tissue pieces were incubated at $37^{\circ} \mathrm{C}$ in the absence or presence of phenylephrine at $10^{-4} \mathrm{M}$ in KRB buffer containing $0.5 \%$ BSA for 10 to 120 minutes. The 
supernatant was removed and the tissue was homogenized in homogenization buffer. The amount of EGF protein in both the supernatant and the tissue homogenate was measured in duplicate by enzyme-linked immunosorbent assay (ELISA). Microtiter plates (Nunc, Maxisorp) were coated with the medium or homogenate diluted in $50 \mathrm{mM}$ carbonate buffer at $\mathrm{pH} 9.6$ and incubated overnight at $4{ }^{\circ} \mathrm{C}$. After removing the target protein solution, non-specific protein binding sites were blocked by incubating with PBS containing 1\% BSA for 2 hours at room temperature, followed by the incubation with anti-rat EGF polyclonal antibody for 1 hour at room temperature. After washing with PBS containing 0.05\% Tween 20, HRP-conjugated donkey anti-goat IgG antibody diluted in blocking buffer was added for 1 hour at room temperature. The plates were washed three times in $0.05 \%$ Tween 20-PBS, washed once in 50 $\mathrm{mM}$ Tris- $\mathrm{HCl}(\mathrm{pH} 8.0)$, and peroxidase activity was measured in duplicate using Amplex Red. The amount of fluorescence was quantified as described for secretion assays. EGF release was expressed as the percent EGF protein secreted into the medium compared to total EGF protein in the tissue homogenate plus the medium.

\section{Data presentation and statistical analysis}

Data are expressed as fold increase above basal value, which was standardized to 1.0. Results are expressed as mean \pm SEM. Data were analysed by one-way analysis of variance (ANOVA) followed by Bonferroni/Dunn test to compare basal and post-stimulation value or Student's $t$ test. $P<0.05$ was considered statistically significant.

\section{RESULTS}

\section{Identification of $\alpha_{1}$-AR Subtype in Lacrimal Gland Acini}

To determine which $\alpha_{1}$-adrenergic receptors are present in rat lacrimal gland, membranes from acinar cells were isolated by centrifugation. Saturation and competition curves were generated using ${ }^{125}$ I-HEAT, the $\alpha_{1 \mathrm{~A}}$-AR inhibitor 5-MU and the $\alpha_{1 \mathrm{D}}$-AR inhibitor BMY-7378 (38). 5MU is 50-100 fold more selective for $\alpha_{1 \mathrm{~A}}$-ARs than $\alpha_{1 \mathrm{~B}}-$ or $\alpha_{1 \mathrm{D}^{-}}$ARs whereas BMY-7378 is 100 fold more selective for $\alpha_{1 D^{-}}$ARs than $\alpha_{1 A^{-}}$or $\alpha_{1 B^{-}}$ARs. As shown in Figure $1 \mathrm{~A}$, saturation studies were performed by incubating the membranes with increasing concentrations (35-600 $\mathrm{pM}$ ) of ${ }^{125}$ I-HEAT in the presence and absence of $0.1 \mathrm{mM}$ phentolamine. These experiments (Figure 1) indicated that lacrimal gland acini contain $0.206 \pm 0.033$ pmol of adrenergic receptors/mg protein. Data obtained from competition studies with 5-MU (Figure 1B) show a one site binding model of low affinity indicating that $\alpha_{1 \mathrm{~A}}$-ARs are not present in lacrimal gland acini. Competition studies performed with BMY-7378 (Figure 1C) show a two site binding model indicating that a majority (approximately $90 \%$ ) of $\alpha_{1}$-adrenergic receptors present are low affinity $\alpha_{1 \mathrm{~B}}$-ARs while the remainder of the $\alpha_{1}$-ARs are high affinity $\alpha_{1 \mathrm{D}}$-ARs.

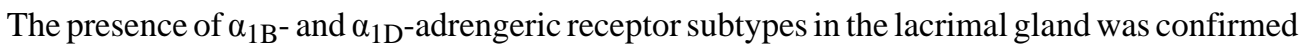
using RT-PCR. RNA was isolated from lacrimal gland acini from three individual animals and from the brain of one of the animals, and cDNA was synthesized. PCR was then performed using primers specific to rat $\alpha_{1 \mathrm{~A}^{-}}, \alpha_{1 \mathrm{~B}^{-}}$, and $\alpha_{1 \mathrm{D}^{-}} \mathrm{ARs}$ and the housekeeping gene G3PDH. As shown in Figure 1D, PCR products of the expected sizes were obtained when using the primers for $\alpha_{1 \mathrm{~B}^{-}}$and $\alpha_{1 \mathrm{D}}$-ARs while no product was detected using $\alpha_{1 \mathrm{~A}^{-}} \mathrm{AR}$ primers. As a positive control PCR products for $\alpha_{1 \mathrm{~A}^{-}}, \alpha_{1 \mathrm{~B}^{-}}$, and $\alpha_{1 \mathrm{D}^{-}}$adrenergic receptors were detected in brain. As a control for the quality of the CDNA, PCR was also performed at the same time with the same cDNA as used for the $\alpha_{1}$-ARs using primers for G3DPH. A single band of the appropriate molecular weight was detected with this primer. In addition, PCR was performed in the absence of cDNA (negative control, NC). 


\section{$\alpha_{1 D}$-ARs Mediate Lacrimal Gland Functions}

As phenylephrine is a potent stimulator of lacrimal gland secretion, we determined which of the $\alpha_{1}$-AR subtypes mediates phenylephrine-induced protein secretion. Acini were preincubated for 20 minutes with BMY-7378 from $10^{-11}-10^{-5} \mathrm{M}$ at $37^{\circ} \mathrm{C}$ prior to the addition of phenylephrine $\left(10^{-4} \mathrm{M}\right)$ for 20 minutes. The amount of peroxidase secreted into the media was then measured as described. As shown in Figure 2A, BMY-7378 statistically significantly inhibited peroxidase secretion a maximum of $82.7 \pm 6.5 \%$, at $10^{-7} \mathrm{M}$, respectively. Interestingly, this response is biphasic and indeed $10^{-5} \mathrm{M}$ BMY-7378 is significantly different from $10^{-7}$ M. BMY-7378 alone had no significant effect of peroxidase secretion at any concentration (data not shown). Using the specific $\alpha_{1 \mathrm{~A}}$-adrenergic inhibitor 5-MU, phenylephrine induced-secretion was reduced, though not significantly, a maximum of $30.0 \pm$ $15 \%$ at $10^{-8} \mathrm{M}$ (data not shown).

We have previously shown that phenylephrine stimulates the activation of p42/p44 MAPK in lacrimal gland acinar cells through transactivation of the EGF receptor (21). To determine if p42/p44 MAPK activation is also mediated by $\alpha_{1 D^{-A R s}}$, acini were preincubated with BMY-7378 from $10^{-11}-10^{-5} \mathrm{M}$ for 20 minutes at $37^{\circ} \mathrm{C}$ and then stimulated with phenylephrine $\left(10^{-4} \mathrm{M}\right)$ for 5 minutes. The amount of phosphorylated p42/p44 MAPK was determined by Western blot techniques. BMY-7378 statistically significantly inhibited phenylephrine-induced p42/p44 MAPK activation by $66.0 \pm 15.0 \%, 81.0 \pm 10.0 \%, 92.0 \pm 7.0$ $\%, 86.3 \pm 11.8 \%$ and $100 \pm 0 \%$ at $10^{-9}, 10^{-8}, 10^{-7}, 10^{-6}$, and $10^{-5} \mathrm{M}$, respectively (Figure 2B). BMY-7378 alone had no significant effect of MAPK activation at any concentration (data not shown). These results imply that two phenylephrine-stimulated functions, namely peroxidase secretion and p42/p44 MAPK activation, are mediated by the high affinity $\alpha_{1 D^{-}}$ ARs.

\section{Transactivation of the EGF Receptor by $\alpha_{1 D^{-A R s}}$ occurs via metalloproteinases}

We previously showed that phenylephrine-induced activation of MAPK occurs via transactivation of the EGF receptor though the precise mechanism was not determined (21). As it has been shown in other cell types that EGF, HB-EGF, and TGF $\alpha$ are cleaved by MMPs into their soluble forms that transactivate the EGF receptor $(13,17,24)$, we tested whether, in the lacrimal gland, transactivation of EGF receptor by phenylephrine occurs via MMP cleavage of a member of the EGF family. The effects of a broad spectrum MMP inhibitor GM6001 and its negative control, and an inhibitor specific for ADAM17, TAPI-1 $(20,29)$, on peroxidase secretion were determined. As phenylephrine activation of MAPK decreases secretion, inhibition of MAPK stimulation would increase secretion. Thus, if GM6001 or TAPI-1 inhibits EGF release, phenylephrine-stimulated secretion would increase. Lacrimal gland acini were preincubated with GM6001 $\left(10^{-6} \mathrm{M}\right)$, its negative control $\left(10^{-6} \mathrm{M}\right)$, or TAPI-1 $\left(10^{-4}-10^{-6}\right.$ M) for 20 minutes prior to stimulation with phenylephrine $\left(10^{-4} \mathrm{M}\right)$ for 20 minutes. GM6001 statistically significantly increased peroxidase secretion by $143.6 \pm 14.8 \%$. The negative control compound for GM6001 did not statistically significantly increase phenylephrineinduced peroxidase secretion (Figure 3A). As GM6001 is a broad spectrum inhibitor for MMPs, we also tested the effects of an inhibitor to ADAM 17, TAPI-1. TAPI-1 statistically significantly increased peroxidase secretion at $10^{-5} \mathrm{M}$ by $120.2 \pm 6.3 \%$ (Figure 3B). TAPI-1 alone had no effect on peroxidase secretion (data not shown).

Lacrimal gland acini were preincubated with with GM6001 $\left(10^{-6} \mathrm{M}\right)$, its negative control $\left(10^{-6} \mathrm{M}\right)$, TAPI- $1\left(10^{-4}-10^{-6} \mathrm{M}\right)$ for 20 minutes prior to stimulation with phenylephrine $\left(10^{-4} \mathrm{M}\right)$ for 5 minutes. $\mathrm{p} 42 / \mathrm{p} 44$ MAPK activation was then measured using Western blot techniques. Phenylephrine significantly increased p42/p44 MAPK activation (Figure 3C and D). Incubation with GM6001 reduced the amount of activated MAPK while the negative control compound did not (Figure 3C). TAPI-1 $10^{-5}$ and $10^{-4} \mathrm{M}$ also reduced the amount of 
activated MAPK (Figure 3D). When 7 independent experiments were analyzed, GM6001 significantly reduced the amount of activated MAPK by $57.1 \pm 21.8 \%$. TAPI- $110^{-5}$ and $10^{-4} \mathrm{M}$ significantly reduced phenylephrine-induced $\mathrm{p} 42 / \mathrm{p} 44$ MAPK by $32.7 \pm 15.8 \%$ and $81.1 \pm 13.9 \%$, respectively in six independent experiments (Figure 3F). TAPI-1 alone had no effect on activation of p42/p44 MAPK (data not shown). It is not clear why the TAPI-1 at $10^{-4} \mathrm{M}$ did not further increase protein secretion as p42/p44 MAPK activation was inhibited by $80 \%$. While we do not understand this, we believe that since MAPK activation is upstream from protein secretion, it is possible that additional factors come into play between the upstream effector (MAPK) and the endpoint (secretion) accounting for the loss of effect. This is particularly likely as phenylephrine activates specific pathways that stimulate secretion (e.g. $\mathrm{PKC} \varepsilon$ ) and others that inhibit secretion (e.g. PKC $\alpha,-\delta)(39)$.

These data indicate that phenylephrine activates an MMP, perhaps ADAM17, to release a member of the EGF family, which activates the EGF receptor and MAPK ultimately leading to an inhibition of protein secretion.

\section{Location of EGF in the lacrimal gland}

EGF is synthesized in a precursor form (approx. $170 \mathrm{KDa}$ ) that is cleaved to the proEGF form (approx. $150 \mathrm{kDa}$ ) and the mature form (approx. $6 \mathrm{kDa}$ ). To determine which form of EGF is present in the lacrimal gland, the lacrimal gland was homogenized in RIPA buffer or acini were isolated prior to homogenization in RIPA buffer. As shown in Figure 4A, the lacrimal gland homogenate and acini contained a single band at approximately $170 \mathrm{kDa}$ indicating the presence of precursor EGF, and not pro- or mature EGF. As a control, commercially available rat EGF and submandibular gland (which contains only the mature form of EGF) $(15,28)$ were also analyzed by Western blot. The submandibular gland contained only the mature form (6 $\mathrm{kDa}$ ) of EGF (Figure 4A).

The location of EGF in the lacrimal gland is of particular importance due to the highly polarized nature of the acinar cells. EGF located in the apical membrane would be shed into the ducts and onto the ocular surface. EGF located on the basolateral membranes would enter the intracellular space and exert any effects on the acinar cells themselves. To determine the location of EGF in lacrimal gland acini, sections $(6 \mu \mathrm{m})$ of lacrimal gland were examined by immunofluorescence techniques using the antibody directed against EGF used in western blot analysis in Figure 4A. EGF was predominately located in the ducts, and in apical and basolateral membranes of acini of the lacrimal gland (Figure 4B). We did not detect EGF in secretory granules, which is the location seen in the submandibular gland (Figure 4C). The negative control was devoid of staining (Figure 4D). These data indicate that EGF is located in the apical and lateral membranes of acinar cells. Thus, shedding of EGF could influence the acinar cells themselves.

\section{$\alpha_{1}$-Adrenergic agonists stimulate the ectodomain shedding of EGF}

To determine if $\alpha_{1}$-adrenergic agonists increase the shedding of EGF, lacrimal gland pieces were incubated with phenylephrine $\left(10^{-4} \mathrm{M}\right)$ for $0-120$ minutes. At the end of the incubation period, acini were centrifuged, the supernatant was removed and tissue was homogenized. ELISA analysis for EGF was performed on the supernatant while Western blot analysis was performed on the homogenate using an antibody against EGF. Phenylephrine decreased the amount of precursor EGF in lacrimal gland homogenate (Figure 5A) and caused a statistically significant increase in EGF in the supernatant at 30 minutes ( $1.4 \pm 0.2$ fold over control, Figure $5 B)$.

This shedding was statistically significantly inhibited by $55.0 \pm 20.9 \%$ when acini were pretreated with TAPI-1 $\left(10^{-6} \mathrm{M}\right)$ for 20 minutes prior to stimulation with phenylephrine 
$\left(10^{-4} \mathrm{M}\right)$ for 30 minutes (Figure $\left.5 \mathrm{C}\right)$. These results indicate that $\alpha_{1 \mathrm{D}}$-adrenergic agonists cause the shedding of EGF.

\section{The EGF receptor is activated by conditioned media}

To determine if the molecules, including EGF, shed by phenylephrine are biologically active, lacrimal gland pieces were stimulated in KRB with $0.5 \%$ BSA with or without phenylephrine $\left(10^{-4} \mathrm{M}\right)$ for 30 minutes at $37^{\circ} \mathrm{C}$. The conditioned KRB (c-KRB) was removed and the c-KRB was incubated with freshly isolated acini that had been pretreated for 20 minutes with BMY-7378 $\left(10^{-7} \mathrm{M}\right)$. BMY-7378 was added to block any effect that phenylephrine (from the first incubation) might have. The amount of phosphorylated EGF receptor was measured after a 1 min incubation with c-KRB. In acini pretreated with BMY-7378 and stimulated with cKRB from lacrimal gland pieces incubated with phenylephrine, the amount of phosphorylated EGF receptor was increased above that seen in acini preincubated with BMY-7378 and incubated with c-KRB from untreated pieces (Figure 6A). When the results from 4 independent experiments were analyzed, the amount of phosphorylated EGF receptor was statistically significantly increased $1.23 \pm 0.04$ fold increase above cells incubated with c-KRB from untreated lacrimal gland pieces (Figure 6B). When acini were preincubated with the EGF receptor inhibitor AG1478 $\left(10^{-7} \mathrm{M}\right)$ in addition to BMY-7378 for 20 minutes, the amount of phosphorylated EGF receptor was decreased (Figure 6A). When three independent experiments were analyzed, the decrease $(85.0 \pm 23.0 \%)$ was statistically significant. (Figure 6C). AG1478 alone did not have a significant effect on basal MAPK activity $(0.91 \pm 0.24$ fold of basal). These results imply that the EGF receptor is activated by molecules shed in response to phenylephrine.

\section{Active EGF is shed by $\alpha_{1}$-adrenergic agonists and interacts with the EGF receptor to activate p42/p44 MAPK}

To determine if the shed EGF and other molecules cause the phosphorylation of p42/p44 MAPK, through the activation the EGF receptor, lacrimal gland pieces were stimulated in KRB with $0.5 \%$ BSA containing phenylephrine $\left(10^{-4} \mathrm{M}\right)$ for 30 minutes at $37^{\circ} \mathrm{C}$. Again, the c-KRB was removed and incubated with freshly isolated acini that had been pretreated for 20 minutes with BMY-7378 $\left(10^{-7} \mathrm{M}\right)$. These acini were stimulated for 1 minute with the c-KRB. The amount of phosphorylated p42/p44 MAPK increased with the addition of c-KRB from lacrimal gland pieces stimulated with phenylephrine over that seen in acini incubated with media from pieces incubated in the absence of phenylephrine (Figure 7A). When the results from 5 experiments were analyzed, the increase in phosphorylated p42/p44 MAPK was statistically significantly increased $2.38 \pm 0.7$ fold above basal (Figure 7B). When acini were preincubated with AG1478 $\left(10^{-7} \mathrm{M}\right)$ in addition to BMY-7378 for 20 minutes, the amount of phosphorylated p42/p44 MAPK was decreased by $91 \pm 7.4 \%$ compared to acini that were not treated with AG1478 (Figure 7A). This decrease was statistically significant (Figure 7C).

To confirm the identity of the EGF shed in response to $\alpha_{1}$-adrenergic agonist stimulation, the c-KRB from lacrimal gland pieces incubated with phenylephrine was preincubated for 15 minutes with $20 \mu \mathrm{g} / \mathrm{ml}$ of an EGF-neutralizing antibody. Acini were then incubated with the neutralizing antibody mixture for $1 \mathrm{~min}$ and activation of p42/p44 MAPK was measured in acini preincubated with BMY-7378 and incubated with c-KRB. As shown in Figure 8A, activation of $\mathrm{p} 42 / \mathrm{p} 44$ MAPK by incubation with $\mathrm{c}-\mathrm{KRB}$ was decreased by the EGF neutralizing antibody. When 5 independent experiments were analyzed, the EGF neutralizing antibody statistically significantly inhibited by $64.6 \pm 18.8 \%$ (Figure $8 \mathrm{~B}$ ).

To confirm the specificity of the EGF neutralizing antibody, commercially available EGF was preincubated for 15 minutes with the EGF neutralizing antibody used in the previous experiments. The EGF-EGF neutralizing antibody mixture was then added to freshly isolated 
acinar cells for $1 \mathrm{~min}$. EGF alone increased the phosphorylation of p42/p44 MAPK which was inhibited by incubation with the antibody mixture (Figure 8C). When 5 independent experiments were analyzed, the EGF neutralizing antibody statistically significantly inhibited by $66.6 \pm 15.8 \%$ (Figure $8 D$ ). These results indicate that EGF is shed from the lacrimal gland as a result of stimulation with $\alpha_{1}$-adrenergic agonists and interacts with the EGF receptor to activate $\mathrm{p} 42 / \mathrm{p} 44$ MAPK.

\section{DISCUSSION}

In freshly isolated lacrimal gland acini, $\alpha_{1 D^{-}}$ARs have a dual role in protein secretion to both stimulate and reduce it. These receptors produce nitric oxide and increase intracellular cGMP concentrations leading to an increase in protein secretion (10). They also activate $\mathrm{G} \alpha \mathrm{q}$ presumably leading to activation of an, as yet, unidentified phospholipase (19) leading to activation of three isoforms of PKC, namely PKC $\alpha,-\delta$, and $-\varepsilon$ (39). Interestingly, PKC $\alpha$ and $-\delta$ reduce phenylephrine-induced protein secretion from these cells while activation of $\mathrm{PKC} \varepsilon$ stimulates protein secretion. In addition to the classical GPCR pathway, $\alpha_{1 D}$-ARs also transactivate the EGF receptor by activating an MMP, probably ADAM17, to cause the shedding of proEGF. The proEGF binds to the EGF receptor to recruit Shc, Grb2 and SOS leading to the activation of the kinase cascade culminating in the activation of p42/p44 MAPK (21). Activation of p42/p44 MAPK plays a role in modulating phenylephrine-induced protein secretion by reducing it. This probably acts to control protein secretion.

It is worth noting that the inhibition of $\alpha_{1 \mathrm{D}}$-adrenergic receptor-induced protein secretion with BMY-7378 is a biphasic response in that inhibition of secretion reaches a maximum level at $10^{-7} \mathrm{M}$ and is reduced with higher concentrations of BMY-7378. This is in contrast to inhibition

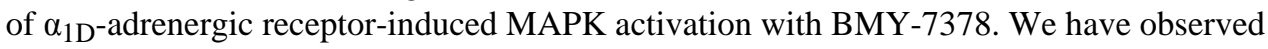
similar results with other inhibitors of $\alpha_{1 \mathrm{D}}$-adrenergic receptor-induced protein secretion, namely with inhibitors of PKC $\alpha$ and $-\delta$ (39). It is unclear why this response is biphasic.

The lacrimal gland contains both $\alpha_{1 \mathrm{~B}^{-}}$and $\alpha_{1 \mathrm{D}^{-}}$-adrenergic receptors. No $\alpha_{1 \mathrm{~A}^{-}}$-adrenergic receptors were detected by either binding or RT-PCR studies. As there are no specific $\alpha_{1 B^{-}}$ adrenergic receptor inhibitors, we were unable to determine the relative role that these receptors play in phenylephrine-induced lacrimal gland functions. However the $\alpha_{1 \mathrm{D}}$-AR inhibitor BMY-7378 completely inhibited both phenylephrine-stimulated protein secretion and p42/p44 MAPK activation at concentrations previously shown to inhibit contraction of rat tail artery (12). It is therefore unlikely that $\alpha_{1 B^{-}}$ARs are involved in these processes. Of interest, $\alpha_{1 D^{-}}$ ARs have been shown to be localized intracellularly (4). Hague et al subsequently showed that in HEK293 cells, co-expression of $\alpha_{1 \mathrm{~B}}$-ARs with $\alpha_{1 \mathrm{D}}$-ARs, results in heterodimers, leading to the expression of $\alpha_{1 \mathrm{D}}$-ARs on the cell surface. In addition, the formation of these heterodimers results in an increase in the coupling of $\alpha_{1 D^{-}}$ARs to intracellular $\mathrm{Ca}^{2+}$ release (8). It is possible that the $\alpha_{1 \mathrm{~B}}$-ARs present in the lacrimal gland play a role in the localization of the $\alpha_{1 \mathrm{D}}$-ARs. Lack of specific antibodies for the AR subtypes makes it difficult to examine this possibility in freshly isolated cells.

$\alpha_{1 \mathrm{D}^{-}}$ARs are present in a variety of tissues $(1,14,18)$. The lacrimal gland contains $0.0206 \mathrm{pmol}$ of $\alpha_{1 \mathrm{D}^{-}}$-adrenergic receptors $/ \mathrm{mg}$ protein. This is in comparison to rat tail artery which has 0.138 pmol of $\alpha_{1 D^{-}}$-adrenergic receptors $/ \mathrm{mg}$ protein and rat aorta which has $0.527 \mathrm{pmol}$ of $\alpha_{1 \mathrm{D}^{-}}$ adrenergic receptors/mg protein (31). Despite widespread distribution, there is limited knowledge regarding the role of $\alpha_{1 D}$-ARs in cellular functions. Few studies have linked activation of $\alpha_{1 \mathrm{D}}$-ARs to functions outside of the vascular tissue. $\alpha_{1 \mathrm{D}}$-ARs have been implicated in smooth muscle contraction in large arteries including the aorta, iliac, and femoral arteries (14). In addition, $\alpha_{1 \mathrm{D}}$-ARs have been shown to activate $\mathrm{p} 42 / \mathrm{p} 44$ MAPK leading to increased protein synthesis in both arterial smooth muscle (36) and fibroblasts (35). However, 
both studies utilized cultured cells overexpressing the $\alpha_{1 \mathrm{D}}$-ARs. In this study, using freshly isolated cells, we show that the $\alpha_{1 \mathrm{D}}$-ARs mediate phenylephrine-stimulated protein secretion and p42/p44 MAPK activation.

It is important to note that these experiments were performed on freshly isolated lacrimal gland acini. These cells have not been modified to overexpress any proteins. It is known that proteins that are overexpressed can result in protein misfolding, changes in rates of degradation, and interactions between proteins that would not normally occur $(5,33)$. Thus it is vital that interactions between proteins be confirmed in wild type, non-transformed cells.

It is well established that EGF is synthesized as a large membrane-bound precursor molecule with a molecular weight of approximately $170 \mathrm{KDa}$. Proteolytic cleavage releases the pro-EGF in a process known as ectodomain shedding which is mediated by a metalloproteinase of the ADAM family (13). This process is similar to those described for other members of the EGF family, namely HB-EGF, TGF $\alpha$, and amphiregulin $(2,11,22,26,30)$. The pro-EGF released is not only soluble, but as it contains EGF domains, is biologically active. Additional proteases present in the extracellular space can further cleave pro-EGF to the mature $6 \mathrm{kDa}$ form of EGF. In the lacrimal gland, we confirmed previous findings from Marechal et al. that EGF is present as only precursor EGF (15). We also demonstrate that it is not present in the secretory granules of the lacrimal gland. This implies that EGF is not secreted but rather is shed by an MMP from the cells from the apical membrane and released into the tears and from the basolateral membranes and released into the extracellular space surrounding acinar cells.

Immunolocalization demonstrated that EGF was present on both the apical membranes, indicating shedding into the tears thereby possibly exerting its effects on the cornea and conjunctiva, and on the basolateral membranes, indicating that EGF can also exert its effects on acinar cells themselves. While we cannot determine from these experiments whether EGF is shed from the apical or basolateral membranes, this study does demonstrate that EGF is shed from lacrimal gland acini, that the shed EGF is biologically active, and that acinar cells are able to respond to this EGF.

In this study we also showed that upon stimulation with $\alpha_{1}$-adrenergic agonists, precursor EGF is cleaved. ProEGF is then shed from the membrane through the actions of a metalloproteinase and is released into the media. TAPI-1, a specific inhibitor of ADAM 17, reduces

phenylephrine-induced activation of p42/p44 MAPK implicating this metalloproteinase in the shedding of EGF in these cells. However, TAPI-1 at $10^{-4} \mathrm{M}$ did not further increase protein secretion as p42/p44 MAPK activation was substantially inhibited. It is possible that because MAPK activation is upstream of protein secretion, downstream proteins play a role in phenylephrine-stimulated protein secretion. However, activation of ADAM 17 is in contrast to the study performed by Sahan et al., who showed that ADAM 10 was the main MMP involved in shedding of EGF (26) from fibroblasts from mice in which different combinations of ADAMs were knocked out. This could be due to a difference in cell types. In addition, we showed that the proEGF released by $\alpha_{1}$-adrenergic agonists is biologically active, as the conditioned buffer can be added to freshly isolated cells and EGF receptor and MAPK can be activated in these cells. Activation of MAPK is partially blocked by an EGF receptor inhibitor, and more importantly, by an EGF neutralizing antibody, confirming the fact that proEGF released binds to the EGF receptor to activate MAPK. It is likely that additional growth factors other than EGF, are also shed in response to $\alpha_{1}$-adrenergic agonists and they could be responsible for the remainder of the MAPK activation not blocked by the EGF receptor inhibitor or the neutralizing antibody.

In summary, in freshly isolated lacrimal gland epithelial cells, $\alpha_{1 \mathrm{D}}$-ARs stimulate protein secretion in addition to the shedding of a biologically active proEGF leading to the 
transactivation of the EGF receptor and activation of p42/p44 MAPK which in turn negatively modulates protein secretion.

\section{References}

1. Arevalo-Leon LE, Gallardo-Ortiz IA, Urquiza-Marin H, Villalobos-Molina R. Evidence for the role of alpha1D- and alpha1A-adrenoceptors in contraction of the rat mesenteric artery. Vascul Pharmacol 2003;40:91-96. [PubMed: 12646397]

2. Arribas J, Coodly L, Vollmer P, Kishimoto TK, Rose-John S, Massague J. Diverse cell surface protein ectodomains are shed by a system sensitive to metalloprotease inhibitors. J Biol Chem 1996;271:11376-11382. [PubMed: 8626692]

3. Brown CL, Meise KS, Plowman GD, Coffey RJ, Dempsey PJ. Cell surface ectodomain cleavage of human amphiregulin precursor is sensitive to a metalloprotease inhibitor. Release of a predominant N-glycosylated 43-kDa soluble form. J Biol Chem 1998;273:17258-17268. [PubMed: 9642297]

4. Chalothorn D, McCune DF, Edelmann SE, Garcia-Cazarin ML, Tsujimoto G, Piascik MT. Differences in the cellular localization and agonist-mediated internalization properties of the alpha(1)-adrenoceptor subtypes. Mol Pharmacol 2002;61:1008-1016. [PubMed: 11961118]

5. Chen J, Acton TB, Basu SK, Montelione GT, Inouye M. Enhancement of the solubility of proteins overexpressed in Escherichia coli by heat shock. J Mol Microbiol Biotechnol 2002;4:519-524. [PubMed: 12432951]

6. El-Shewy HM, Kelly FL, Barki-Harrington L, Luttrell LM. Ectodomain shedding-dependent transactivation of Epidermal Growth Factor receptors in response to Insulin-like Growth factor type I. Mol Endocrinol. 2004

7. Hague C, Chen Z, Uberti M, Minneman KP. Alpha(1)-adrenergic receptor subtypes: non-identical triplets with different dancing partners? Life Sci 2003;74:411-418. [PubMed: 14609720]

8. Hague C, Uberti MA, Chen Z, Hall RA, Minneman KP. Cell surface expression of alpha1D-adrenergic receptors is controlled by heterodimerization with alpha1B-adrenergic receptors. J Biol Chem 2004;279:15541-15549. [PubMed: 14736874]

9. Hodges RR, Dartt DA. Regulatory pathways in lacrimal gland epithelium. Int Rev Cytol 2003;231:129_ 196. [PubMed: 14713005]

10. Hodges RR, Shatos MA, Tarko RS, Vrouvlianis J, Gu J, Dartt DA. Nitric oxide and cGMP mediate a1D-adrenergic receptor-stimulated protein secretion and p42/p44 MAPK activation in rat lacrimal gland. Invest Ophthalmol Vis Sci. 2005In Press

11. Izumi Y, Hirata M, Hasuwa H, Iwamoto R, Umata T, Miyado K, Tamai Y, Kurisaki T, SeharaFujisawa A, Ohno S, Mekada E. A metalloprotease-disintegrin, MDC9/meltrin-gamma/ADAM9 and PKCdelta are involved in TPA-induced ectodomain shedding of membrane-anchored heparinbinding EGF-like growth factor. Embo J 1998;17:7260-7272. [PubMed: 9857183]

12. Kamikihara SY, Mueller A, Lima V, Silva AR, Costa IB, Buratini J Jr, Pupo AS. Differential distribution of functional \{alpha\} 1-adrenergic receptor subtypes along the rat tail artery. J Pharmacol Exp Ther. 2005

13. Le Gall SM, Auger R, Dreux C, Mauduit P. Regulated cell surface pro-EGF ectodomain shedding is a zinc metalloprotease-dependent process. J Biol Chem 2003;278:45255-45268. [PubMed: 12947092]

14. Lluel P, Palea S, Ribiere P, Barras M, Teillet L, Corman B. Increased adrenergic contractility and decreased mRNA expression of NOS III in aging rat urinary bladders. Fundam Clin Pharmacol 2003;17:633-641. [PubMed: 14703725]

15. Marechal H, Jammes H, Rossignol B, Mauduit P. EGF receptor mRNA and protein in rat lacrimal acinar cells: evidence of its EGF-dependent phosphotyrosilation. Am J Physiol 1996;270:C11641174. [PubMed: 8928744]

16. Massague J, Pandiella A. Membrane-anchored growth factors. Annu Rev Biochem 1993;62:515541. [PubMed: 8394682]

17. McCole DF, Keely SJ, Coffey RJ, Barrett KE. Transactivation of the epidermal growth factor receptor in colonic epithelial cells by carbachol requires extracellular release of transforming growth factoralpha. J Biol Chem 2002;277:42603-42612. [PubMed: 12202486] 
18. Mendes FR, Hamamura M, Queiroz DB, Porto CS, Avellar MC. Effects of androgen manipulation on alpha1-adrenoceptor subtypes in the rat seminal vesicle. Life Sci 2004;75:1449-1463. [PubMed: 15240180]

19. Meneray MA, Fields TY. Adrenergic stimulation of lacrimal protein secretion is mediated by G(q/ 11)alpha and G(s)alpha. Curr Eye Res 2000;21:602-607. [PubMed: 11148596]

20. Mohler KM, Sleath PR, Fitzner JN, Cerretti DP, Alderson M, Kerwar SS, Torrance DS, Otten-Evans $\mathrm{C}$, Greenstreet T, Weerawarna K, et al. Protection against a lethal dose of endotoxin by an inhibitor of tumour necrosis factor processing. Nature 1994;370:218-220. [PubMed: 8028669]

21. Ota I, Zoukhri D, Hodges RR, Rios JD, Tepavcevic V, Raddassi I, Chen LL, Dartt DA. Alpha 1adrenergic and cholinergic agonists activate MAPK by separate mechanisms to inhibit secretion in lacrimal gland. Am J Physiol Cell Physiol 2003;284:C168-178. [PubMed: 12388118]

22. Peschon JJ, Slack JL, Reddy P, Stocking KL, Sunnarborg SW, Lee DC, Russell WE, Castner BJ, Johnson RS, Fitzner JN, Boyce RW, Nelson N, Kozlosky CJ, Wolfson MF, Rauch CT, Cerretti DP, Paxton RJ, March CJ, Black RA. An essential role for ectodomain shedding in mammalian development. Science 1998;282:1281-1284. [PubMed: 9812885]

23. Piascik MT, Perez DM. Alpha1-adrenergic receptors: new insights and directions. J Pharmacol Exp Ther 2001;298:403-410. [PubMed: 11454900]

24. Prenzel N, Zwick E, Daub H, Leserer M, Abraham R, Wallasch C, Ullrich A. EGF receptor transactivation by G-protein-coupled receptors requires metalloproteinase cleavage of proHB-EGF. Nature 1999;402:884-888. [PubMed: 10622253]

25. Prenzel N, Zwick E, Leserer M, Ullrich A. Tyrosine kinase signalling in breast cancer. Epidermal growth factor receptor: convergence point for signal integration and diversification. Breast Cancer Res 2000;2:184-190. [PubMed: 11250708]

26. Sahin U, Weskamp G, Kelly K, Zhou HM, Higashiyama S, Peschon J, Hartmann D, Saftig P, Blobel CP. Distinct roles for ADAM10 and ADAM17 in ectodomain shedding of six EGFR ligands. J Cell Biol 2004;164:769-779. [PubMed: 14993236]

27. Schafer B, Gschwind A, Ullrich A. Multiple G-protein-coupled receptor signals converge on the epidermal growth factor receptor to promote migration and invasion. Oncogene 2004;23:991-999. [PubMed: 14647423]

28. Scott J, Patterson S, Rall L, Bell GI, Crawford R, Penschow J, Niall H, Coghlan J. The structure and biosynthesis of epidermal growth factor precursor. J Cell Sci Suppl 1985;3:19-28. [PubMed: 3011823]

29. Slack BE, Ma LK, Seah CC. Constitutive shedding of the amyloid precursor protein ectodomain is up-regulated by tumour necrosis factor-alpha converting enzyme. Biochem J 2001;357:787-794. [PubMed: 11463349]

30. Sunnarborg SW, Hinkle CL, Stevenson M, Russell WE, Raska CS, Peschon JJ, Castner BJ, Gerhart MJ, Paxton RJ, Black RA, Lee DC. Tumor necrosis factor-alpha converting enzyme (TACE) regulates epidermal growth factor receptor ligand availability. J Biol Chem 2002;277:12838-12845. [PubMed: 11823465]

31. Tanaka T, Zhang L, Suzuki F, Muramatsu I. Alpha-1 adrenoceptors: evaluation of receptor subtypebinding kinetics in intact arterial tissues and comparison with membrane binding. Br J Pharmacol 2004;141:468-476. [PubMed: 14718262]

32. Tanida S, Joh T, Itoh K, Kataoka H, Sasaki M, Ohara H, Nakazawa T, Nomura T, Kinugasa Y, Ohmoto $\mathrm{H}$, Ishiguro H, Yoshino K, Higashiyama S, Itoh M. The mechanism of cleavage of EGFR ligands induced by inflammatory cytokines in gastric cancer cells. Gastroenterology 2004;127:559-569. [PubMed: 15300588]

33. Tate CG. Overexpression of mammalian integral membrane proteins for structural studies. FEBS Lett 2001;504:94-98. [PubMed: 11532439]

34. Tepavcevic V, Hodges RR, Zoukhri D, Dartt DA. Signal transduction pathways used by EGF to stimulate protein secretion in rat lacrimal gland. Invest Ophthalmol Vis Sci 2003;44:1075-1081. [PubMed: 12601032]

35. Waldrop BA, Mastalerz D, Piascik MT, Post GR. alpha(1B)- and alpha(1D)-Adrenergic receptors exhibit different requirements for agonist and mitogen-activated protein kinase activation to regulate growth responses in rat 1 fibroblasts. J Pharmacol Exp Ther 2002;300:83-90. [PubMed: 11752101] 
36. Xin X, Yang N, Eckhart AD, Faber JE. Alpha1D-adrenergic receptors and mitogen-activated protein kinase mediate increased protein synthesis by arterial smooth muscle. Mol Pharmacol 1997;51:764775. [PubMed: 9145914]

37. Yano S, Macleod RJ, Chattopadhyay N, Tfelt-Hansen J, Kifor O, Butters RR, Brown EM. Calciumsensing receptor activation stimulates parathyroid hormone-related protein secretion in prostate cancer cells: role of epidermal growth factor receptor transactivation. Bone 2004;35:664-672. [PubMed: 15336602]

38. Zhong H, Minneman KP. Alpha1-adrenoceptor subtypes. Eur J Pharmacol 1999;375:261-276. [PubMed: 10443582]

39. Zoukhri D, Hodges RR, Sergheraert C, Toker A, Dartt DA. Lacrimal gland PKC isoforms are differentially involved in agonist-induced protein secretion. Am J Physiol 1997;272:C263-269. [PubMed: 9038832] 
A

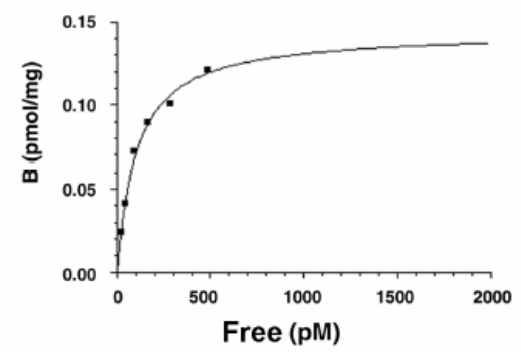

B

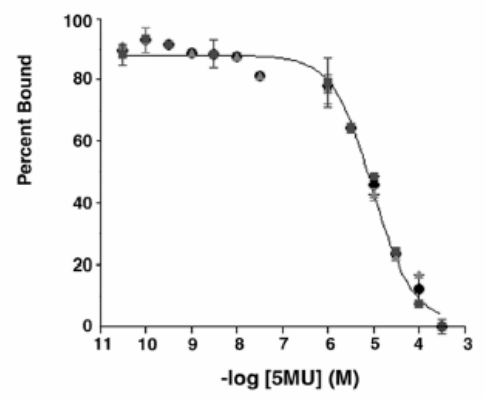

C
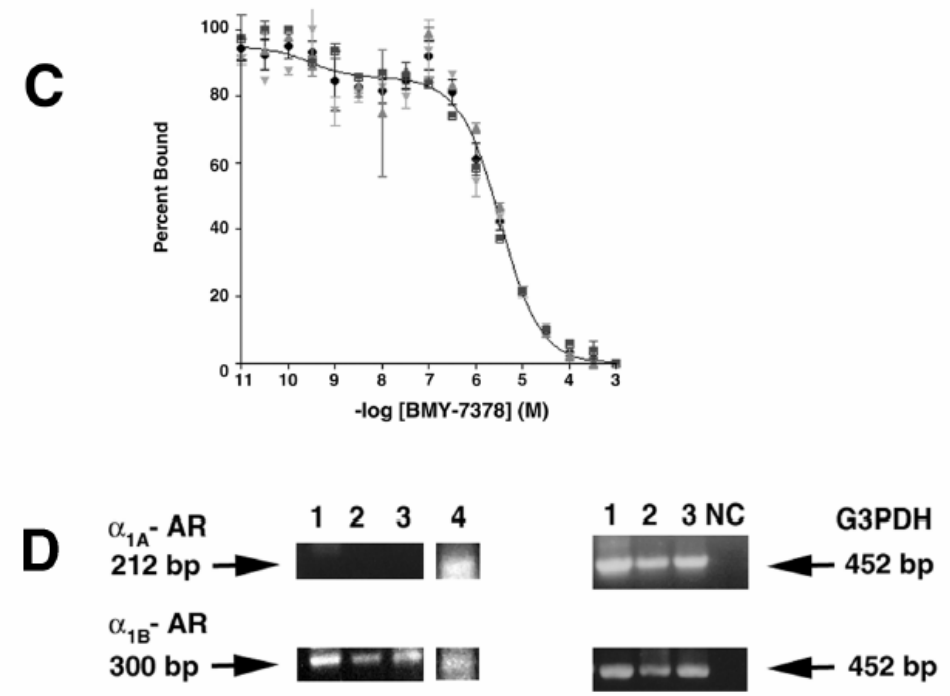

$\alpha_{1 D^{-}}$AR

304 bp

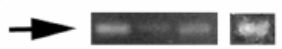

$-\infty$

452 bp

Figure 1. Binding, Competition and RT-PCR Studies

Saturation studies were performed by incubating lacrimal gland membranes with increasing concentrations of ${ }^{125} \mathrm{I}$-HEAT in the presence or absence of $0.1 \mathrm{mM}$ phentolamine. Specific binding is shown for a representative curve (A). $\mathrm{Bmax}=0.206 \pm 0.033$ pmoles $/ \mathrm{mg}$ membrane protein; $\mathrm{K}_{\mathrm{D}}=107.8 \pm 10.7 \mathrm{pM}$ from 3 independent experiments performed in triplicate.

Competition studies were performed using the $\alpha_{1 \mathrm{~A}}$-adrenergic receptor selective inhibitor 5methylurapidil (5-MU) (B) or the $\alpha_{1 \mathrm{D}}$-adrenergic receptor selective inhibitor BMY7378 (C) from $10 \mathrm{pM}$ to $1 \mathrm{mM}$ in the presence of $90 \mathrm{pM}^{125} \mathrm{I}$-HEAT. Various symbols present data from individual experiments $(\mathrm{n}=4)$, performed in duplicate. (D) RT-PCR was performed on lacrimal gland acini and brain mRNA using primers specific to $\alpha_{1 \mathrm{~A}^{-}}, \alpha_{1 \mathrm{~B}^{-}}, \alpha_{1 \mathrm{D}^{-}}$adrenergic receptors or 
G3PDH. Each lane (1, 2, and 3) corresponds to an individual animal. Lane 4 corresponds to RT-PCR performed with each primer using brain mRNA. NC - Negative Control. 
A

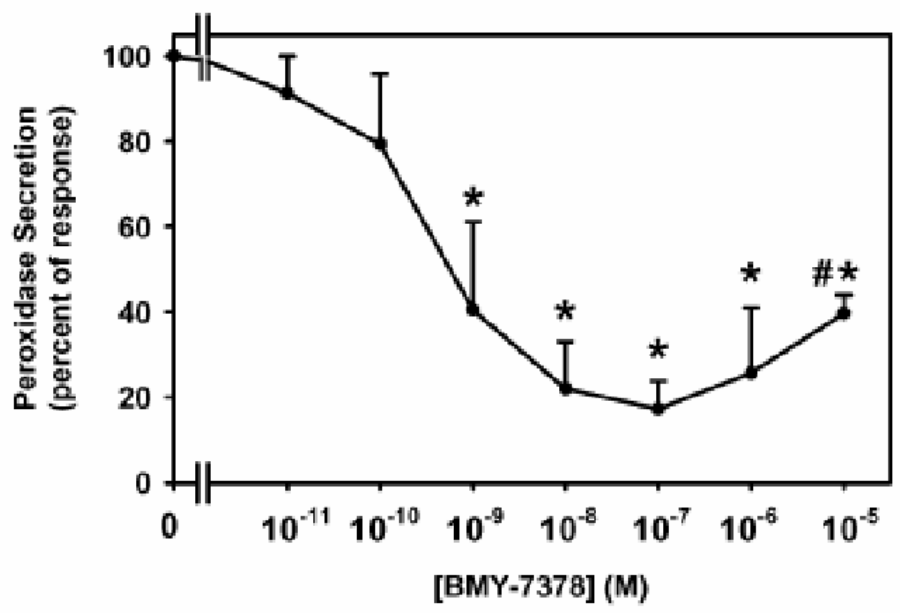

B

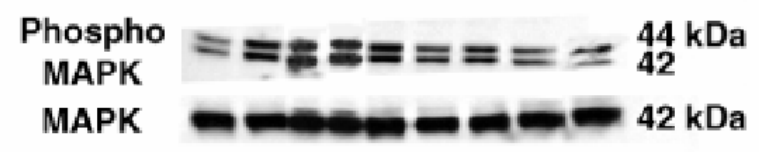

B Ph $10^{-11} 10^{-10} 10^{-19} 10^{-8} 10^{-7} 10^{-6} 10^{-5}$

BMY 7378 (M)

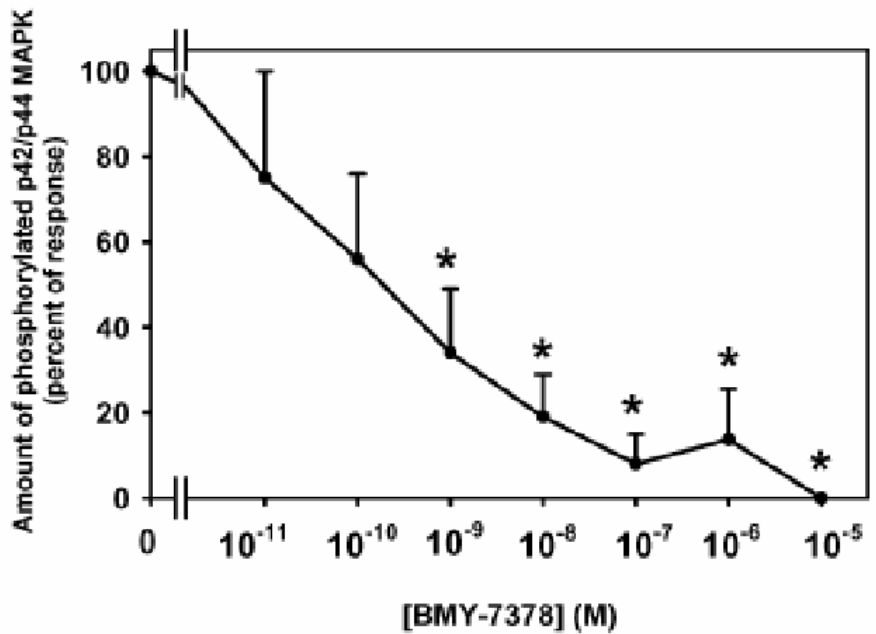

Figure 2. Effect of Inhibition of $\alpha_{10}$-Adrenergic Receptors on Lacrimal Gland Functions Lacrimal gland acini were preincubated for 20 minutes with the specific $\alpha_{1 \mathrm{D}}$-adrenergic receptor inhibitor BMY-7378 $\left(10^{-11}-10^{-5} \mathrm{M}\right)$ prior to addition of the $\alpha_{1}$-adrenergic agonist phenylephrine $\left(10^{-4} \mathrm{M}\right)$ and $(\mathbf{A})$ peroxidase secretion was measured after 20 minutes. Data are mean \pm SEM of percent of response from 3-6 independent experiments. (B) p42/p44 MAPK was measured after 5 minutes. Data are mean \pm SEM of percent of response from 4-8 independent experiments. The blot shown in $\mathbf{B}$ is a representative blot. * indicates statistical significance from no BMY-7378; \# indicates statistical significance from $10^{-5} \mathrm{M}$ BMY-7378. 
A

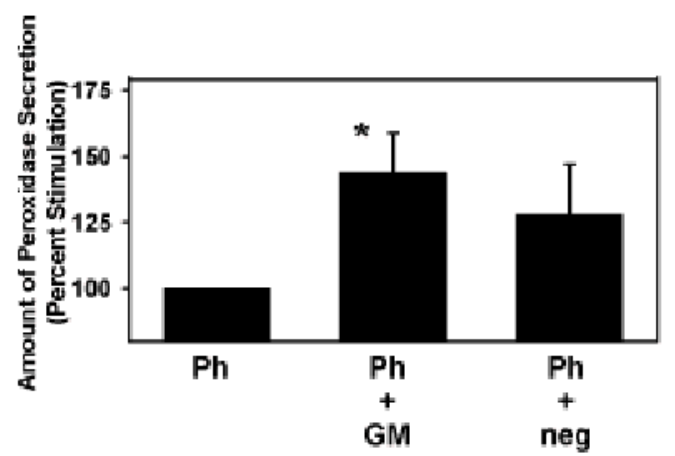

C

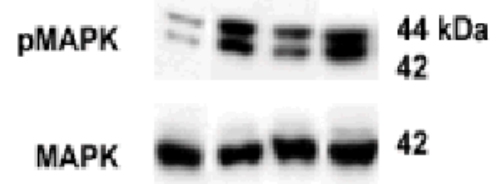

B Ph $\mathrm{Ph}$ Ph
$\stackrel{+}{+} \underset{+}{\mathrm{GM}}$ neg

$\mathbf{E}$

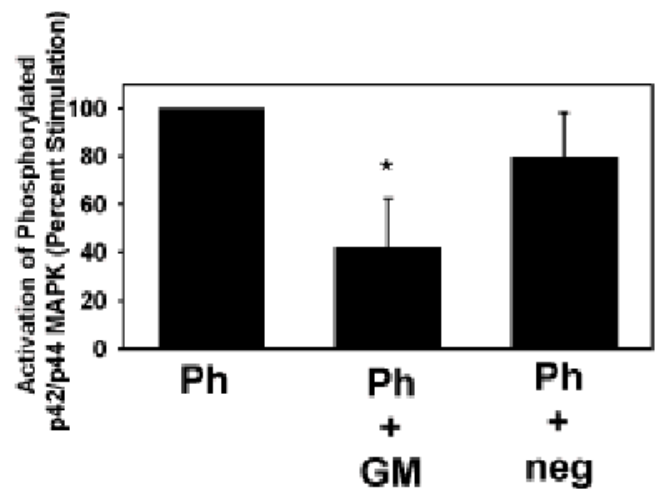

B

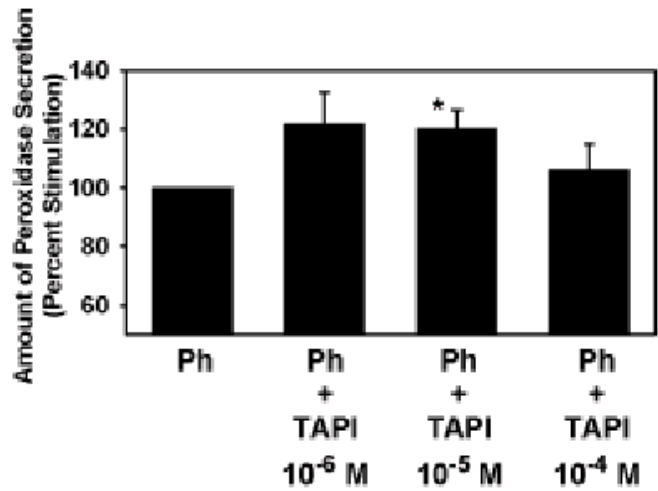

D

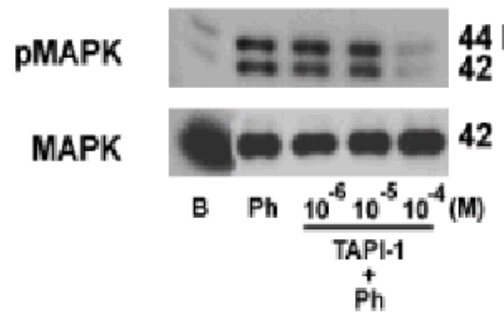

$\mathbf{F}$

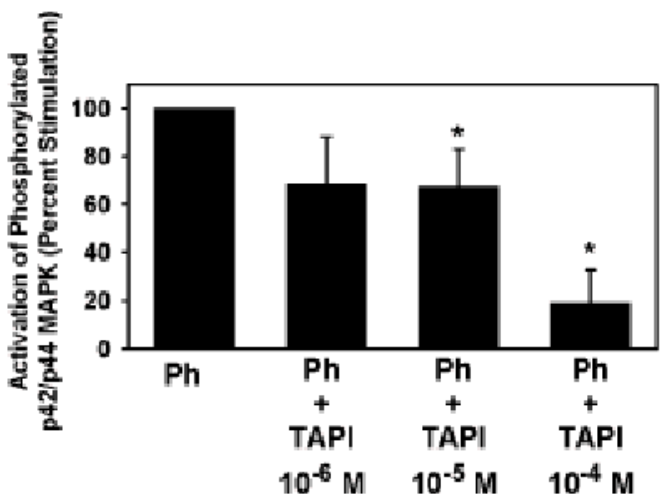

Figure 3. Effect of Inhibition of Matrix Metalloproteinases on Lacrimal Gland Functions Lacrimal gland acini were preincubated for 20 minutes with either GM6001, its negative control $\left(10^{-6} \mathrm{M}, \mathbf{A}\right)$ or ADAM-17 inhibitor TAPI- $1\left(10^{-4}-10^{-6} \mathrm{M}, \mathbf{B}\right)$ prior to addition of the $\alpha_{1}$-adrenergic agonist phenylephrine $\left(10^{-4} \mathrm{M}\right)$ and peroxidase secretion was measured after 20 minutes. Data are mean \pm SEM from 6 independent experiments. Acini were preincubated for 20 minutes with either GM6001, its negative control $\left(10^{-6} \mathrm{M}, \mathbf{E}\right)$ or ADAM-17 inhibitor TAPI-1 $\left(10^{-4}-10^{-6} \mathrm{M}, \mathbf{F}\right)$ prior to addition of the $\alpha_{1}$-adrenergic agonist phenylephrine $\left(10^{-4} \mathrm{M}\right)$ and $\mathrm{p} 42 / \mathrm{p} 44 \mathrm{MAPK}$ was measured after 5 minutes. Data are mean \pm SEM from 6 independent experiments. Blots shown in $\mathbf{C}$ and $\mathbf{D}$ are representative experiments. * indicates statistical significance from agonist alone. 

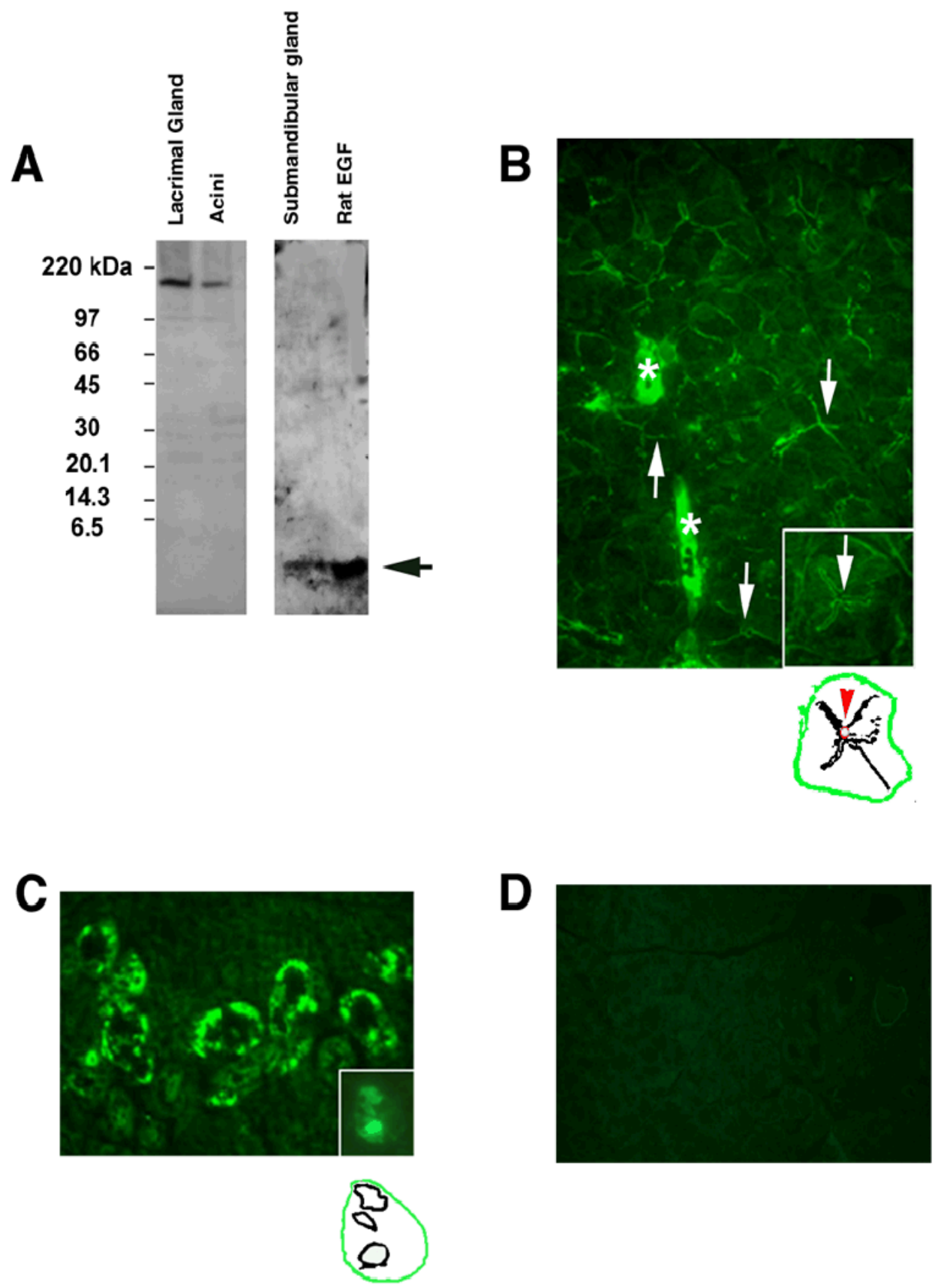

Figure 4. Presence of EGF in the Lacrimal Gland

(A) Proteins from either lacrimal gland homogenate or acini were separated on 4-20\% polyacrylamide gel and EGF was detected in whole lacrimal gland, isolated lacrimal gland acini, commercially available rat EGF, and whole submandibular gland using an anti-EGF antibody. Arrow indicates the $6 \mathrm{kDa}$ EGF form of EGF. (B) Localization of EGF was determined by immunofluorescence techniques in lacrimal gland. * indicate the presence of EGF in lacrimal gland ducts; arrows indicate the presence of EGF in the apical and lateral membranes of lacrimal gland acinar cells. Inset shows presence of EGF in apical and lateral membranes of lacrimal gland acinar membranes. A schematic diagram of the structure of a lacrimal gland acinus is below with the apical membrane highlighted in red and with the red 
arrowhead. Green indicates basal membranes while black indicates lateral membranes. (C) Localization of EGF was determined by immunofluorescence techniques in submandibular gland. Inset shows EGF in secretory granules in submandibular glands. A schematic diagram of the structure of a submandibular gland acinar cell is below with the basal membrane shown in green. Black indicates secretory granules. (D). Negative control. Magnification $\times 600$. Inset magnification in $\mathbf{B}$ and $\mathbf{C} \times 1000$. 
A

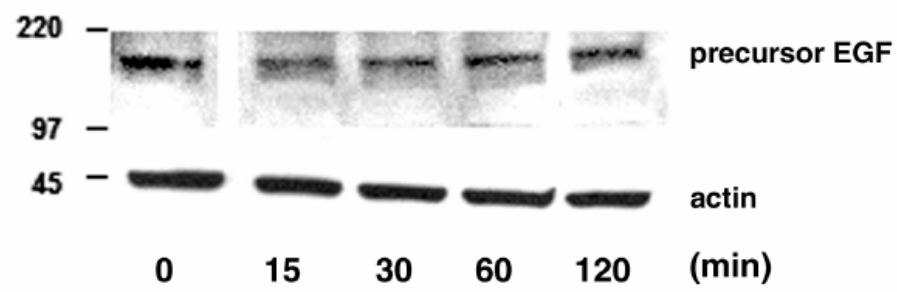

B

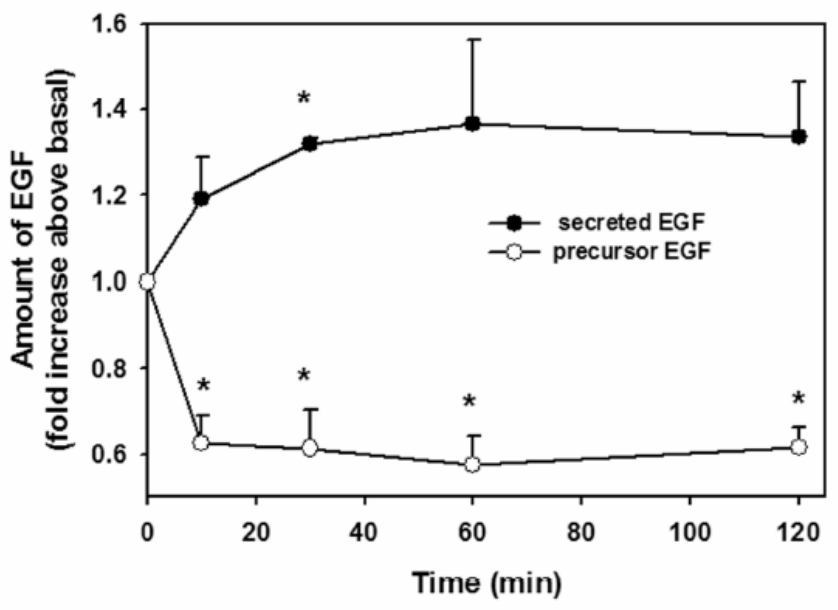

C

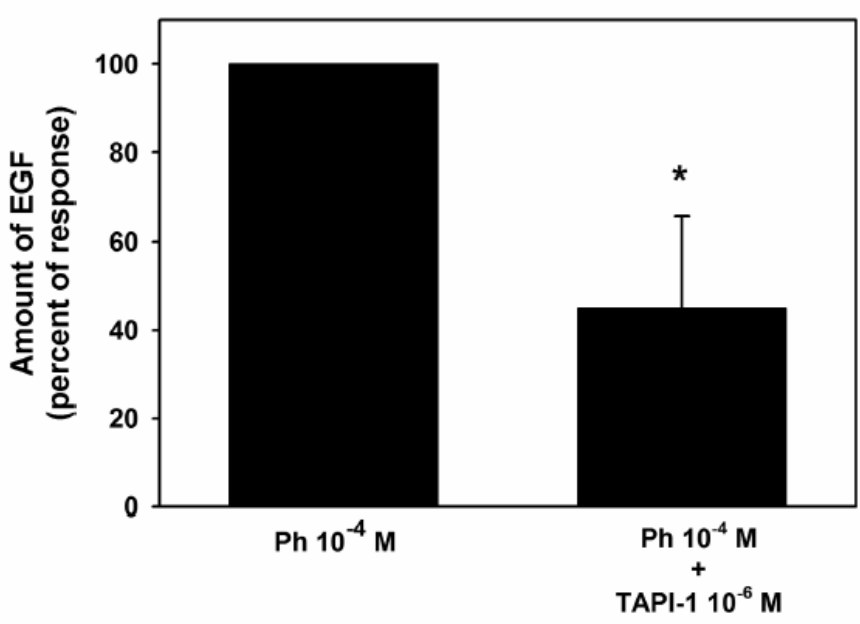

Figure 5. Effect of $\alpha_{\mathbf{1}}$-Adrenergic Agonists on Ectodomain Shedding of EGF

Lacrimal gland pieces were incubated with the $\alpha_{1}$-adrenergic agonist phenylephrine $\left(10^{-4} \mathrm{M}\right)$ for 0-120 minutes. A. Tissue was homogenized and proteins separated on 4-20\% polyacrylamide gel and Western blot analysis was performed using an antibody against either EGF or F-actin. B. Western blots from A were scanned, quantified, and the amount of precursor EGF was standardized to the amount of F-actin. After incubation with phenylephrine, the incubation media was collected and the amount of EGF was determined by ELISA using the same antibody used in A (secreted EGF). Data are mean \pm SEM of four independent experiments. * indicates statistical significance from 0 time. C. Acini were preincubated with TAPI-1 for 20 minutes prior to stimulation with phenylephrine for 30 minutes. The amount of 
EGF present in the media was determined by ELISA using the same antibody used in A. Data are mean \pm SEM of four independent experiments. $*$ indicates statistical significance from phenylephrine alone. 


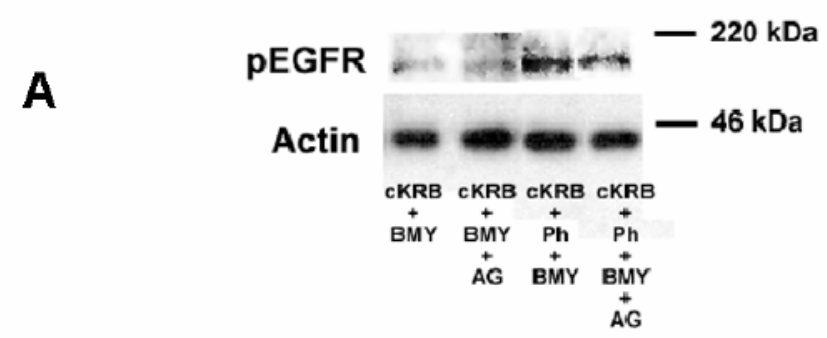

B
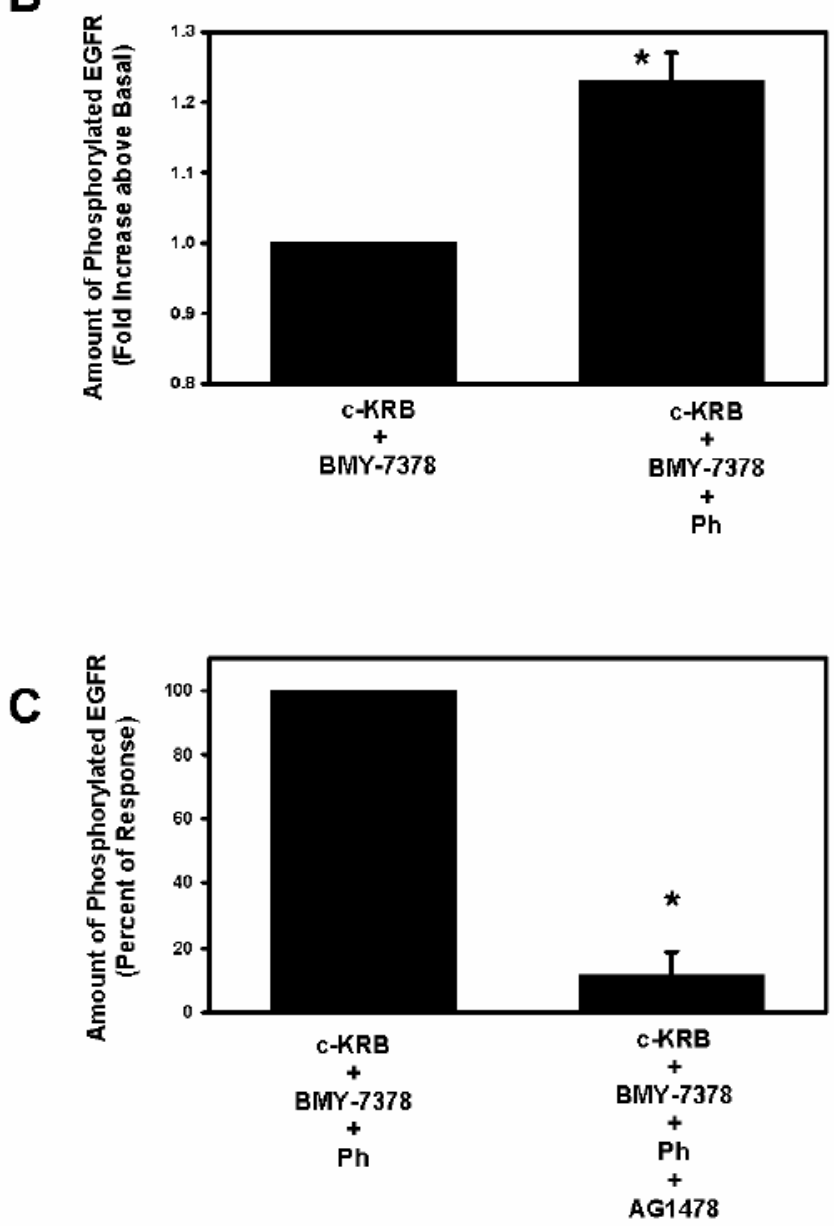

Figure 6. EGF shed by $\alpha_{1}$-Adrenergic Agonists is Biologically Active and Interacts with the EGF receptor

Lacrimal gland pieces were incubated with either no additions or the $\alpha_{1}$-adrenergic agonist phenylephrine $\left(10^{-4} \mathrm{M}\right)$ for 30 minutes. The conditioned media (c-KRB) was removed and added to acini pretreated with the $\alpha_{1 \mathrm{D}^{-}}$adrenergic receptor inhibitor BMY-7378 $\left(10^{-7} \mathrm{M}\right)$ for $1 \mathrm{~min}$. The amount of EGF receptor phosphorylation was measured by Western blot analysis. A representative blot is shown in (A). Experiments were quantified and the amount of EGF receptor standardized to actin and shown in $(\mathbf{B})$. Data are mean \pm SEM of four independent experiments. Acini were preincubated with AG1478 $\left(10^{-7} \mathrm{M}\right)$ for 20 minutes. c-KRB was added for $1 \mathrm{~min}$. Experiments were quantified and the amount of EGF receptor was 
standardized to actin and shown in $(\mathbf{C})$. Data are mean \pm SEM of three independent experiments. 
A

\section{Figure 7. EGF shed by $\alpha_{1}$-Adrenergic Agonists activates p42/p44 MAPK}

Lacrimal gland pieces were incubated with either no additions or the $\alpha_{1}$-adrenergic agonist phenylephrine $\left(10^{-4} \mathrm{M}\right)$ for 30 minutes. The conditioned media (c-KRB) was removed and added to freshly isolated acini pretreated for 20 minutes with BMY-7378 $\left(10^{-7} \mathrm{M}\right)$. The amount of p42/p44 MAPK activation was measured after $1 \mathrm{~min}$ by Western blot analysis. A representative blot is shown in (A). Experiments were quantified and the amount of phosphorylated p42/p44 MAPK standardized to total p42/p44 MAPK and shown in (B). Data are mean \pm SEM of five independent experiments. Acini were preincubated with AG1478 $\left(10^{-7} \mathrm{M}\right)$ for 20 minutes before stimulation with c-KRB. Experiments were quantified and the 
amount of p42/p44 MAPK activation was measured by Western blot analysis and shown in (C). Data are mean \pm SEM of three independent experiments. 
A
B

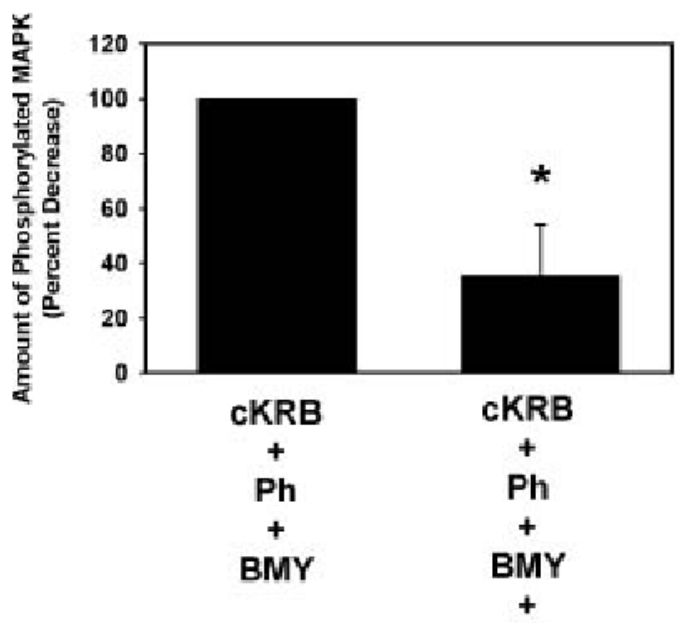

Ab
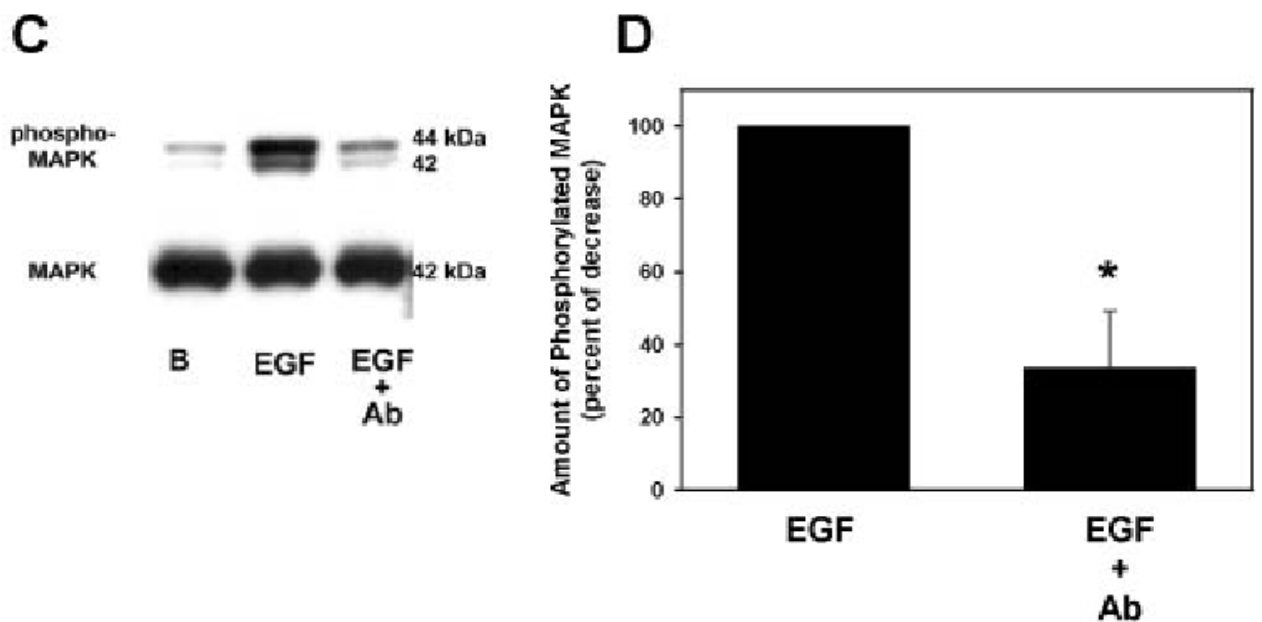

Figure 8. Biologically Active EGF Shed by by $\alpha_{1}$-Adrenergic Agonists Lacrimal gland pieces were incubated with either no additions or the $\alpha_{1}$-adrenergic agonist phenylephrine $\left(10^{-4} \mathrm{M}\right)$ for 30 minutes. The conditioned media (c-KRB) was removed and incubated for $15 \mathrm{~min}$ with an EGF neutralizing antibody $(20 \mu \mathrm{g} / \mathrm{ml})$ before addition to freshly isolated acini pretreated for 20 minutes with BMY-7378 $\left(10^{-7} \mathrm{M}\right)$. A representative blot is shown in A. Experiments were quantified and the amount of p42/p44 MAPK activation was measured by Western blot analysis and shown in $\mathbf{B}$. Data are mean \pm SEM of five independent experiments. As a control for the antibody specificity, exogenous EGF $\left(10^{-7} \mathrm{M}\right)$ was preincubated for $15 \mathrm{~min}$ with the EGF neutralizing antibody $(20 \mu \mathrm{g} / \mathrm{ml})$ before addition to freshly isolated acini. A representative blot is shown in $\mathbf{C}$. Experiments were quantified and the amount of p42/p44 MAPK activation was measured by Western blot analysis and shown in D. Data are mean \pm SEM of five independent experiments. 